\title{
Quality and management of wastewater in sugar industry
}

\author{
Pradeep Kumar Poddar • Omprakash Sahu
}

Received: 3 February 2014 / Accepted: 6 January 2015/Published online: 2 November 2014

(C) The Author(s) 2015. This article is published with open access at Springerlink.com

\begin{abstract}
Wastewater from sugar industries is one that has complex characteristics and is considered a challenge for environmental engineers in terms of treatment as well as utilization. Before treatment and recycling, determination of physicochemical parameter is an important mechanism. Many different types of techniques are introduced and modified for the purpose, but depend upon the water quality parameters. The main aim of this study is to determine the physicochemical characteristics of sugar industry waste water by the standard method and minimize the fresh water consumption in sugar industry by water pinch methodology.
\end{abstract}

Keywords Effluent · Fresh water - Lime ·

Physicochemical · Steam

\section{Introduction}

Sugar is one of the most important substrates for human diet and it is an essential product of the human life. Sugarcane is a valuable crop for bio-products because it produces sugar which has very high demand in the market and also bagasse which provides energy in the form of fuel for the generation of electricity and steam (Renouf et al. 2008). Bagasse is used as input resource in 80 sugarcane producing countries (Botha and Blottnitz 2006). In the past,

\section{P. K. Poddar}

Department of Chemical and Natural Resources Engineering,

University Malaysia Pahang, Kauntan, Malaysia

O. Sahu (ه)

Department of Chemical Engineering, NIT Raipur, Raipur, CG, India

e-mail: ops0121@gmail.com sugar industry produced only sugar but nowadays sugar industries are involved in the production of sugar, electricity and ethanol. So sugar industry is now called as the cane industry (Ramjeawon 2008). The top five nations, viz., India, Brazil, Thailand, Australia, and China accounted for nearly $40 \%$ of the total sugar production in the world. Sugar is produced approximately in 115 countries in the world. Out of these, 67 countries produce sugar from sugarcane, 39 from sugar beets and 9 countries from sugarcane as well as sugar beets (Lichts 2007). In other words, sugar is produced $70 \%$ from sugarcane and $30 \%$ from sugar beet and cassava, etc. (Contreras et al. 2009). In the world, Brazil and India are holding first and second rank in sugarcane production countries, respectively. Though, each produces 275 million tons of sugarcane (Macedo 1998; Prakash et al. 1998). India is the second largest producer of sugar in the world. In the year of 2012-2013, 526 mills are operated in India, which produced 33.90 million tons of sugar (ISMA 2014).

Sugar industry is basically seasonal in nature and operates only for 150-210 days in a year (November to May) (Kolhe et al. 2009). A significantly large volume of waste is generated during the manufacture of sugar and contains a high amount of pollution load, particularly in terms of suspended solids, organic matter, and press mud, bagasse and air pollutants. Several chemicals are used in sugar industries mainly for coagulation of impurities and refining of end products. $\mathrm{Ca}(\mathrm{OH})_{2}$ is used to clarify and to increase $\mathrm{pH}$ of juices. A small quantity of $\mathrm{H}_{3} \mathrm{PO}_{4}$ is added prior to liming to improve clarification (Kushwaha 2013). $\mathrm{CO}_{2}$ gas is bubbled through the defected juice to lower $\mathrm{pH}$, which result in the improvement of precipitation of impurities. Polyelectrolytes, which are polymer-based chemical, are also used for coagulation impurities during defection and carbonation process. $\mathrm{SO}_{2}$ is bubbled through the 
defected raw sugar to remove colour. Dilute solution of $\mathrm{NaOH}$ or $\mathrm{Na}_{2} \mathrm{CO}_{3}$ is used for the periodic descaling of heater followed by neutralizing it with dilute $\mathrm{HCl}$. Lead subacetate is used for the analysis of sugar content. These entire chemicals, one-way or another, are contributing towards increasing the organic strength, dissolved solid and suspended matter (Jadhav et al. 2013). Industrialization is considered the cornerstone of development strategies due to its significant contribution to the economic growth and human welfare. It has become a yardstick for placing countries in the League of Nations and an index of its political stature. Industrialization, like other human activities that impact on the environment, often results in pollution and degradation. Industries turn out wastes which are peculiar in terms of type, volume and frequency depending on the type of industry and population that uses the product (Adekunle and Eniola 2008). Environmentalists and scholars in other disciplines have attempted to examine the impact of industrial activities on the physico-chemical parameters and heavy metal concentration of rivers/streams (Ahmad and Mahmoud 1982; Ogedengbe and Akinbile 2004; Fakayode 2005; Chaudhari et al. 2005), while others carried out a bacteriological assessment (Ahmad and Mahmoud 1982).

The purpose of the work is to determine the physical (like, pH, EC, TDS, Temperature), Chemical (like, Sodium, Potassium, Calcium, Magnesium, Chloride, Carbonate, Bicarbonate, Sulphate), and physicochemical (like, DO, COD and BOD) characteristics of effluent (APHA 1995). The second part of this work (minimization) consumption of waste in sugar industry was carried out by pinch methodology.

\section{Materials and methods}

\section{Materials}

The waste water was collected from Bhoramdev Sugar Industry Ltd. Kavardha (C.G.) India. The initial water quality parameter is mentioned in Table 1 and it was preserved at $20{ }^{\circ} \mathrm{C}$ until used. The laboratory reagent (LR) grade chemicals were used in the experiments and analytical (AR) grade chemicals were used for analysis. These LR and AR grade chemicals were obtained from Merk Chemical Ltd., Mumbai, India.

Methods

(a) To determine the physicochemical characteristics: The samples were collected and analysed for temperature, $\mathrm{pH}$, total solids (TS), total dissolved solids (TDS), total suspended solids (TSS), chloride content,
Table 1 Physicochemical parameters of sugar industry waste water

\begin{tabular}{lll}
\hline S. no & Parameters & Parameter \\
\hline 1 & Colour & Dark yellow \\
2 & Odour & Fishery \\
3 & pH & 5.5 \\
4 & DO & 1.5 \\
5 & BOD & $970 \mathrm{mg} / 1$ \\
6 & COD & $3,682 \mathrm{mg} / 1$ \\
7 & Oil and grease & $12 \mathrm{mg} / 1$ \\
8 & Temperature & $40{ }^{\circ} \mathrm{C}$ \\
9 & Electrical conductivity & $2.23 \mathrm{~S} \mathrm{~cm}{ }^{-1}$ \\
10 & Total dissolved solid & $1,480 \mathrm{mg} / 1$ \\
11 & Suspended solid & 790 \\
12 & Dissolved solid & 1,650 \\
13 & Chloride & 250 \\
14 & Calcium & $361 \mathrm{mg} / 1$ \\
15 & Magnesium & $268 \mathrm{mg} / 1$ \\
16 & Sulphate & $419 \mathrm{mg} / 1$ \\
17 & Iron & $12.8 \mathrm{mg} / 1$ \\
18 & Lead & $0.065 \mathrm{mg} / 1$ \\
19 & Zinc & $0.26 \mathrm{mg} / 1$ \\
20 & Copper & $0.135 \mathrm{mg} / 1$ \\
21 & Potassium & $113 \mathrm{mg} / 1$ \\
22 & Phosphate & $5.9 \mathrm{mg} / \mathrm{l}$ \\
\hline Excet & &
\end{tabular}

$\overline{\text { Except colour, } \mathrm{pH} \text {, conductivity and temperature all values are in } \mathrm{mg} / \mathrm{l}}$

oil/grease, bio-chemical oxygen demand (BOD) and chemical oxygen demand (COD) values. The techniques and methods followed for collection, preservation, analysis and interpretation are those given by Rainwater and Thatcher (1990); Brown et al. (1970); ICMR (1975); APHA (1995).

(b) To minimized the wastage of water: To accomplish the objective of minimized fresh water consumption and waste water disposal, water pinch methodology was used. This methodology can be broken down into six steps for obtaining good results (Yoo et al. 2006):

1. Find flow data. Develop a simple flow sheet model of the water system, showing where water is used, and where (waste) water is generated.

2. Develop a water balance accurate to within $10 \%$ of the metered amounts of the larger streams. Define the appropriate data for the Water Pinch analysis, i.e. determine water 'sources' and 'sinks'.

3. Select key contaminants-e.g. COD, salts, suspended solids. In this paper, COD was selected as a key contaminant.

4. Run water pinch analysis Carry out the water pinch analysis to determine optimum matches 
between sources and sinks. Examine the sensitivity plots, relax constraints.

5. Review design Examine the resulting network design. Repeat steps 3-5 until a practical design has been evolved.

Some flow rates were quantified on the basis of process mass balances or estimates.

\section{Physicochemical characteristics of waste water}

\section{Colour}

Colour is a qualitative characteristic that can be used to assess the general condition of wastewater. Wastewater that is light brown in colour is less than $6 \mathrm{~h}$ old, while a light-to-medium grey colour is characteristic of wastewaters that have undergone some degree of decomposition or that have been in the collection system for some time. Lastly, if the colour is dark grey or black, the wastewater is typically septic, having undergone extensive bacterial decomposition under anaerobic conditions (Buvaneswaril et al. 2013). The blackening of wastewater is often due to the formation of various sulphides, particularly ferrous sulphide. This results when hydrogen sulphide produced under anaerobic conditions combines with divalent metal, such as iron, which may be present. In the present investigation, the colour of the untreated effluent was dark yellow. Similar studies by different authors found that the colour was dark brownish (Kolhe et al. 2009) black (Samuel and Muthukkaruppan 2011), yellow (Baskaran et al. 2009), and reddish yellow (Hampannavar and Shivayogimath 2010). Colour is very important factor for the aquatic life for making food from sun-rays. This photosynthetic activity reduced due to dark colouration affects other parameters such temperature D.O. and B.O.D.

\section{Odour}

From the available data, it was observed that untreated SIWW have fishery odour Unpleasant odours in food industry wastewater are usually caused by gases produced by anaerobic decomposition of organic matter. The most common odour causing compound is hydrogen sulphide whose characteristic odour is that of rotten eggs (Metcalf and Eddy 2003). Sulphur is required in the synthesis of proteins and is released into the degradation process. Under anaerobic conditions, sulphate is reduced biologically to sulphide which can further combine with hydrogen forming hydrogen sulphide $\left(\mathrm{H}_{2} \mathrm{~S}\right)$. This gas is readily soluble in water, colourless and inflammable, but also toxic. Although hydrogen sulphide is the most common gas formed during the anaerobic decomposition of organic matter when considering odours, other volatile compounds, such as indole, skatole and mercaptans, may cause odours far more unpleasant than $\mathrm{H}_{2} \mathrm{~S}$. Some other gases, such as carbon dioxide resulting from the decomposition of organic matter or nitrogen dissolved from the atmosphere, are also responsible for odour. The control of odours has become more important in the designing and operating of wastewater collection, treatment and disposal plants. Odours are the foremost concern of the public in wastewater treatment processes. Quite often, the psychological stress caused by odours is far more important than the harm they do to the health of humans (Droste 1997).

\section{Temperature}

Temperature is basically important for its effect on certain chemical and biological radiations taking place in water for organism and inhabiting aquatic media. It was observed that temperature of the untreated effluent was recorded as $40{ }^{\circ} \mathrm{C}$, and that of the treated effluent was recorded as $30{ }^{\circ} \mathrm{C}$, respectively. The temperature of the discharge should not exceed $35{ }^{\circ} \mathrm{C}$ since high temperature many produce softening of bituminous joints and may be deteropans to the pipe material itself. The rise in temperature accelerated the chemical reaction in oxygen. Salequzzaman et al. (2008) studied the temperature of five different locations and observed that temperature is between 30 and $40{ }^{\circ} \mathrm{C}$.

$\mathrm{pH}$

$\mathrm{pH}$ is the value expressed as the negative logarithm of the hydrogen ion concentration. Its range was give between 0 to 14 , if the value is 7 means neutral less than 7 being acidic and above 7 being basic or alkaline. The wide narration in the $\mathrm{pH}$ value of effluent can affect the rate of biological reaction and survival of various microorganisms. The presence or absence of various ionic special can have direct relation with $\mathrm{pH}$ of the effluent. Subsequently, such effluent can influence the quality of soil (Doke et al. 2011). In the present investigation, the $\mathrm{pH}$ value of the untreated effluents was 5.5 and treated effluent was 7.2 , respectively. Khan et al. (2003) observed a pH 9.5 of the sugar industry effluent.

\section{Dissolved oxygen}

It is one of the most important parameters in water quality assessment. Dissolved oxygen is an index of physical and biological processes in water. The aquatic ecosystem is depends totally on dissolved oxygen; various biochemical changes and its effects on metabolic activities of 
microorganism have been very well documented. The solubility of atmospheric oxygen in freshwater ranges from $14.6 \mathrm{mg} / \mathrm{l}$ at $0^{\circ}$ to about $7.0 \mathrm{mg} / \mathrm{l}$ at $35^{\circ}$ less than one atmospheric pressure; since it is a poorly suitable gas, its solubility directly varies with the atmospheric pressure at any given temperature. It was found that the sugar industry untreated effluent was $1.50 \mathrm{mg} / \mathrm{l}$ and the treated effluent was $2.52 \mathrm{mg} / \mathrm{l}$, respectively, in this study. Avasan and Rao (2001) observed that the DO of sugar mill ranged between 0 and 2.0. He observed that if DO is low, then it causes anoxic conditions. This causes respiratory distress of fish, which shows erratic movements. Devi (1980) also reported high DO during monsoon and low during summer in Asmaansagar. Mohan (1980) recorded dissolved oxygen range as $4.61-6.68 \mathrm{mg} / \mathrm{l}$ in the winter season.

\section{Total solids}

The term solid refers to the matter either filtrable or infiltrable that remains as residue upon venerating and subsequent drying at a defined temperature employed for drying and ignition. In effluent, the total solids, total dissolved solids and total suspended solids are composed mainly of carbonates bicarbonates, chlorides, sulphates, nitrates, $\mathrm{Ca}$, $\mathrm{Mg}, \mathrm{Na}, \mathrm{K}, \mathrm{Mn}$ and organic matter silts and other particles polluting water increase the concentration of total solids. Presently, it was investigated that the range of total solids in untreated effluent was $1,480 \mathrm{mg} / \mathrm{l}$. Senthi et al. (2001) observed that the effluent discharged from sugar mill ranged between $4,485.0$ and $1,520 \mathrm{mg} / \mathrm{l}$ with increasing distance $(0-5 \mathrm{~km})$. Avasan and Rao (2001) observed that the total solids from the Tummanals sugar factory effluent ranged between 870 and $1,950 \mathrm{mg} / \mathrm{l}$. Amathussalam and Jayabai (2002) observed that the total solids from the sugar industry effluent ranged between 1,979 and 1,820 mg/l.

Total suspended solids

The T.S.S. affects the light intensity of water; suspended solids are the cause of suspended particles inside the water body influencing turbidity and transparency. Effluents from different industries have different amounts of solid particulate matter, either as suspended solids or total dissolved solids. It was observed that suspended solids of untreated effluent were $790 \mathrm{mg} / \mathrm{l}$ and treated effluent $100 \mathrm{mg} / \mathrm{l}$, respectively. Ahmad and Mahmoud (1982) studied that the total suspended solid of sugar industry effluent was $1,620 \mathrm{mg} / \mathrm{l}$.

Total dissolved solids

The total solid concentrations in waste effluent represent the colloidal form and dissolved specters. It might be the fluctuation or the values of total solids and subsequent; the value of dissolved solid is due to convent collision of the colliding particles. The rate of collision of aggregated process is also influenced by $\mathrm{pH}$ of these effluents. In the rainy season, less concentration of total dissolved solids is obtained due to the dilution of waste effluent with rain water. From the experimental result, it was observed that the dissolved solids of untreated effluents were $1,650 \mathrm{mg} / \mathrm{l}$ and treated samples are $1,030 \mathrm{mg} / \mathrm{l}$, respectively. Avasan and Rao (2001) observed that the total dissolved solids of sugar mill effluent ranged between 400 and $1,650 \mathrm{mg} / \mathrm{l}$. Thorat and Wagh (1990) studied tannery waste and observed total dissolved solids in effluent $2,850 \mathrm{mg} / \mathrm{l}$.

\section{Chlorides}

Chlorides are generally present in natural water. The presence of chloride in natural water is attributed to dissolution of salt deposits' discharge of effluents from chemical industries oil well operations, sewage discharges initiation drainage, contamination from refuse leachates, and sea water intrusion in coastal area. In the present study, chlorides of untreated effluents were $205 \mathrm{mg} / \mathrm{l}$ and treated effluent showed $170 \mathrm{mg} / \mathrm{l}$. Matkar and Gangotri (2002) observed that the effluents from sugar industry have 450 and $455 \mathrm{mg} / \mathrm{l}$ untreated effluent and the treated effluent was 156 and $162 \mathrm{mg} / \mathrm{l}$ in November and December, respectively.

\section{Biochemical oxygen demand}

Biochemical oxygen demand is defined as amount of oxygen required by microorganism while stabilizing biological decomposable organic matter in waster aerobic conditions. Biological oxygen demand is an important parameter that indicates the magnitude of water pollution, by the oxidizable organic matter and the oxygen used to oxidize inorganic materials, such as sulphides and ferrous ions. In natural source, the oxidizable matter on oxidation enters into biogeochemical cycle. It was found that the biological oxygen demand of untreated effluents BOD was $970 \mathrm{mg} / \mathrm{l}$ and treated effluent showed $300 \mathrm{mg} / \mathrm{l}$, respectively. Senthi et al. (2001) observed in the summer season the BOD of sugar mill effluent to be $635-950 \mathrm{mg} / \mathrm{l}$ range. He observed the value of BOD for the sugar mill effluent and it varied from 950 to $635 \mathrm{mg} / \mathrm{l}$ with flowing distance.

\section{Chemical oxygen demand}

The COD test determines the oxygen required for chemical oxidation of organic matter with the help of strong chemical oxidant. The COD is a test, which is used to measure 
pollution of domestic and industrial waste. The waste is measured in terms of quality of oxygen required for the oxidation of organic matter to produce carbon dioxide and water. The conjugation of BOD test with COD test is helpful in indication of toxic conditions and the presence of biological resistance. From the initial investigation, it was observed that the COD of untreated effluents was $3,682 \mathrm{mg} / \mathrm{l}$ and can be reduced up to $300 \mathrm{mg} / \mathrm{l}$, respectively. Devi et al. (2008) observed COD 22,000 mg/l on coffee processing waste water. Importance of organic matter in the ecology of bloom firming cyanobacteria has been reported by many workers. Samuel and Muthukkaruppan (2011) observed that the effluent of sugar industry waste water loaded $3,146 \mathrm{mg} / \mathrm{l}$ which is not suitable for seed growth.

\section{Sulphate}

Sulphate is polyatomic ions, which occurred in natural water as well as it has been used in different industry. Effluent from certain industries also may be major sources of sulphate to the receiving water. Sulphur itself has never been a limiting factor in aquatic systems. The normal levels of sulphates are more than adequate to meet plant needs; odour conditions are easily greater when water is overloaded with organic waste to the point that oxygen is removed, so that $\mathrm{SO}_{4}$ as electron acceptor is often used for the breakdown of organic matter and produces $\mathrm{H}_{2} \mathrm{~S}$ and rotten egg smell (Welch 1998). In the present study, sulphate of untreated effluents was $419 \mathrm{mg} / \mathrm{l}$ and treated effluent $220 \mathrm{mg} / \mathrm{l}$. Manal (2002) observed sulphate in sugar industry effluent that was 550 and $555 \mathrm{mg} / \mathrm{l}$ in November and December, respectively, in which untreated and treated effluents showed 256 and $262 \mathrm{mg} / \mathrm{l}$ in November and December, respectively. Senthi et al. (2001) observed that sulphate ranged between 200 and $93 \mathrm{mg} / \mathrm{l}$ according to flowing distance from effluent discharging unit to $5 \mathrm{~km}$ long. This indicates that as the distance increases from the outlet, the value of sulphate decreases.

\section{Oil and grease}

The concentration of dispersed oil and grease (OG) is an important parameter for water quality and safety. Among other pollutants, oil and grease is one of the most complicated pollutants to remove. Determination of oil and grease concentrations in effluent does not determine the presence of specific substances, but groups of substances that can be extracted from a sample using a particular effluent. Oil, grease, fats and waxes are dissolved in suitable solvent and separated from the aqueous phase. The solvent layer is then evaporated and the residue is weighed as oil and grease. In the present study, oil and grease present in untreated effluents were $12 \mathrm{mg} / \mathrm{l}$ and the treated effluent showed $9 \mathrm{mg} / \mathrm{l}$ respectively. Manal (2002) reported that oil and grease in sugar industry effluent ranged between 14 and $11 \mathrm{mg} / \mathrm{l}$ (untreated).

\section{Management (minimization of losses)}

The selected process/unit is firstly divided into sinks and sources' streams. Sinks streams are categorized as inlet streams of the selected unit/process and the outlet streams are considered as sources. However, freshwater and waste water are also placed under sources category as some of the waste streams cannot be used/reused as sources to the unit (Mehrdadi et al. 2007). In the sugar process, water requirements are the followings: imbibitions, process water use, lime make up water, flocculants make up water, filter wash, pan house requirements and service water requirements. The use of external supplies should be kept to a minimum, because they inflate the quantity to be disposed of ultimately. It is possible for a mill to exist without an external supply, provided water circuits in the mill are carefully managed (Nakane and Haidary 2010).

A scheme showing the water flows in a sugar process production is appeared in Fig. 1. During the sugar production water flow in mill is appeared in Fig. 1 and water leaving the mill in following ways: (a) Together with the products of the mill: in molasses and in filter cake. (b) In the form of vapor in: boiler gases, which may or may not be saturated, depending on whether a wet scrubber is used; vapor evaporated in cooling towers or spay pond; flash vapor from the heated juice flash tank; evaporation from diffuser or mills. (c) In liquid form as: surplus condensate; overflow from the cooling water circuit; boiler blow down; drift loss from the cooling towers or spray pond; effluent (wash down or spillage) from drains. From the process analysis, we identified 12 source streams with opportunities to be recycled and 6 sinks, as shown in Tables 2 and 3.

Target for fresh water is determined by considering all the sinks and sources in the process. The sinks and sources are arranged in ascending order of their maximum property loads as property loads are analogous to mass loads (Kazantzi and El-Halwagi 2005). El- Halwagi and Prakash have shown that the ascending arrangement of sources and sinks, respectively, provides a simplified target and design arrangement (El-Halwagi et al. 2003; Prakash and Shenoy 2005). Table 2 shows the result obtained after water balance of source. The flow of source is expressed in $\mathrm{kg} / \mathrm{s}$; it was found that total flow of sources is $29.98 \mathrm{~kg} / \mathrm{s}$. The composition was found only in few sources, which is expressed in $\mathrm{mg}$ sugar/kg of water. The source maximum property is calculated by (1): 
Fig. 1 Major water flow in sugar industry

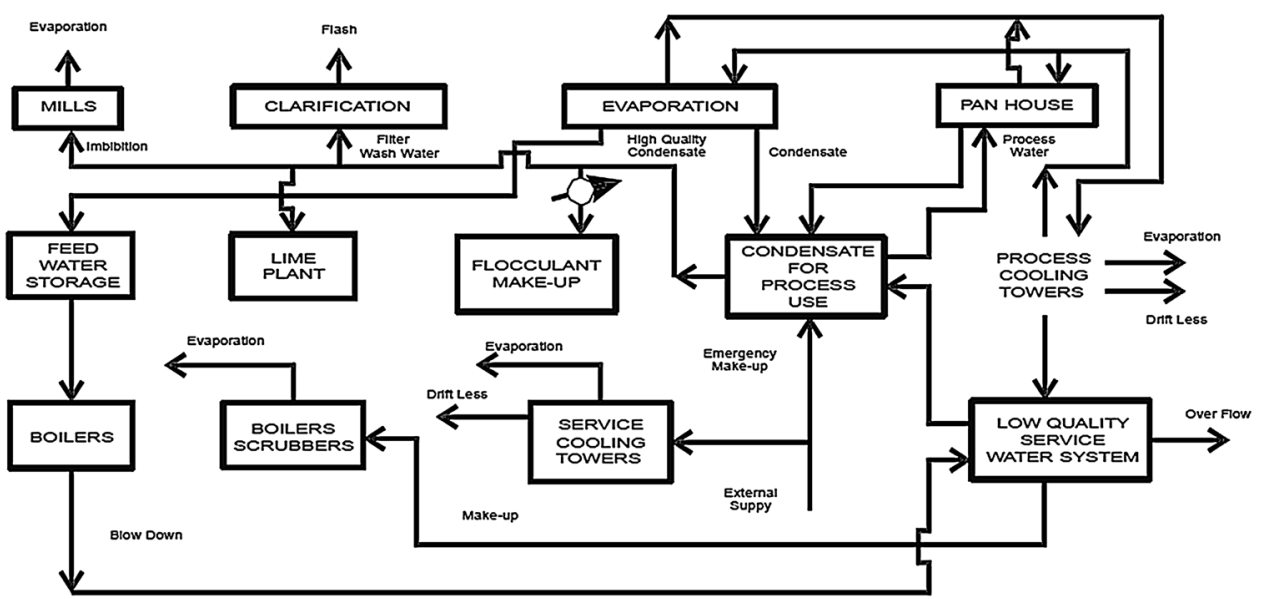

$M_{i}^{\text {Sourcre,max }}=W_{i} * Y_{i}^{\max }$

where $W i$ is the flow rate, $M_{i}^{\text {Sourcre,max }}$ is admissible maximum load, $Y_{i}^{\max }$ is maximum property value for source stream. The result from water for sink is shown in Table 3. The total water requirement is $23.98 \mathrm{~kg} / \mathrm{s}$ and composition varies from 10 to $80 \mathrm{mg}$ sugar $/ \mathrm{kg}$ of water. The maximum property load of a sink is calculated by (2):

$M_{j}^{\text {sink,max }}=G_{j} * Z_{j}^{\max }$

where $G_{j}$ is flow rate, $M_{j}^{\text {Sink, max }}$ is admissible maximum load $Z_{j}^{\max }$ is maximum property value for sink stream. After calculating the loads of each sink and source stream, the process has requirement of water equal to $1,980.57 \mathrm{~m}^{3} /$ day; from these $1,056.46 \mathrm{~m}^{3} /$ day is fresh water and $2,736.29 \mathrm{~m}^{3} /$ day of water are disposed as aqueous waste; this disposable waste can be recycled. Mathematical optimization was carried out using Water Pinch ${ }^{\mathrm{TM}}$ software to achieve an optimal distribution of flows. Since operations

Table 2 Water balance for sources

\begin{tabular}{lcc}
\hline Source & $\begin{array}{l}\text { Flow } \\
(\mathrm{kg} / \mathrm{s})\end{array}$ & $\begin{array}{l}\text { Composition } \\
(\mathrm{mg} \text { sugar/kg water) }\end{array}$ \\
\hline Condensate from heater 2 & 1.37 & 55 \\
Condensate from heater 3 & 1.10 & 60 \\
Condensate pre-evaporator & 7.30 & 0 \\
Condensate VI & 3.30 & 23 \\
Condensate V2 & 2.64 & 43 \\
Condensate V3 & 6.50 & 48 \\
Condensate V4 & 2.74 & 54 \\
Condensate pan 1 & 0.91 & 0 \\
Condensate pan 2 & 0.90 & 0 \\
Condensate pan 3 & 1.21 & 0 \\
Condensate pan 4 & 0.62 & 0 \\
Condensate pan 5 & 0.92 & 0 \\
Condensate pan 6 & 0.62 & 0 \\
Total flow of source & 30.13 &
\end{tabular}

lose freshwater, which is discharged as wastewater, it is necessary to separate water losses from utilized water within processes (Ataei et al. 2009). After that, maximum environmental concentration is considered for each contaminant and each operation. The goal of function was to minimize the fresh water consumption with constraints levels of contaminants in the flows and mass balances constraints.

Minimum flow rate is deducted from flow rate of the most polluted stream and the rest is considered for other polluted streams. Therefore, the cleanest stream remains as a last alternative for treatment. In this method, contaminants are treated to get appropriate concentration for using by all processes. The matrix and redistribution of streams to minimization of fresh water consumption is shown in Table 4. From the data, it is clearly that outlet streams enter the regeneration unit in the pinch point and having been regenerated, they are reused or recycled into operations.

The outlet treatment concentration may not be usable for all processes, so this concentration is used by process, in which inlet contaminant concentration is equal to or greater than outlet treatment concentration. Accordingly, although the maximum treatment flow rate is considered for regeneration, it can be less, more or equal to actual flow rate

Table 3 Water balance for sinks

\begin{tabular}{lrl}
\hline Sinks & $\begin{array}{c}\text { Flow } \\
(\mathrm{kg} / \mathrm{s})\end{array}$ & $\begin{array}{l}\text { Composition } \\
(\mathrm{mg} \text { sugar/kg water) }\end{array}$ \\
\hline Mill (imbibition) & 6.91 & $0-80$ \\
Boiler & 12.53 & $0-10$ \\
Lime make up water & 0.14 & $0-40$ \\
Filter wash & 1.06 & $0-80$ \\
Centrifuges & 0.29 & $0-80$ \\
First heater & 1.29 & $0-40$ \\
Total water & 22.22 & \\
requirement & & \\
\hline
\end{tabular}


Table 4 Matrix and redistribution of steam to minimization of fresh water consumption

\begin{tabular}{|c|c|c|c|c|c|c|}
\hline Flow $(\mathrm{kg} / \mathrm{s})$ & Mills & Boiler & Lime & Filter & Centrifuges & First heater \\
\hline Fresh water & 0.00 & 0.00 & 0.00 & 0.00 & 0.00 & 0.00 \\
\hline Condensate heater 2 & 0.00 & 0.00 & 0.00 & 0.00 & 0.00 & 0.00 \\
\hline Condensate heater & 0.00 & 0.00 & 0.00 & 0.00 & 0.00 & 0.00 \\
\hline Condensate pre-evaporator & 0.00 & 7.29 & 0.00 & 0.00 & 0.00 & 0.00 \\
\hline Condensate V1 & 1.87 & 0.68 & 0.07 & 0.00 & 0.28 & 0.41 \\
\hline Condensate V2 & 1.87 & 0.00 & 0.00 & 0.00 & 0.00 & 0.00 \\
\hline Condensate V3 & 1.87 & 0.00 & 0.00 & 1.06 & 0.00 & 0.88 \\
\hline Condensate V4 & 0.38 & 1.87 & 0.00 & 0.00 & 0.00 & 0.00 \\
\hline Condensate pan 1 & 0.91 & 0.00 & 0.00 & 0.00 & 0.00 & 0.00 \\
\hline Condensate pan 2 & 0.00 & 0.90 & 0.00 & 0.00 & 0.00 & 0.00 \\
\hline Condensate pan 3 & 0.00 & 1.21 & 0.00 & 0.00 & 0.00 & 0.00 \\
\hline Condensate pan 4 & 0.00 & 0.00 & 0.00 & 0.00 & 0.00 & 0.00 \\
\hline Condensate pan 5 & 0.00 & 0.00 & 0.00 & 0.00 & 0.00 & 0.00 \\
\hline Condensate pan 6 & 0.01 & 0.59 & 0.01 & 0.00 & 0.00 & 0.00 \\
\hline Total consumption & 6.91 & 12.53 & 0.14 & 1.06 & 0.29 & 1.29 \\
\hline
\end{tabular}

Table 5 Consumption and availability of water after optimization

\begin{tabular}{llll}
\hline $\begin{array}{l}\text { Quality of } \\
\text { water }\end{array}$ & $\begin{array}{l}\text { Consumption } \\
\mathrm{m}^{3} / \text { day }\end{array}$ & $\begin{array}{l}\text { Average } \\
\mathrm{m}^{3} / \text { day }\end{array}$ & $\begin{array}{l}\text { Subtotal } \\
\mathrm{m}^{3} / \text { day }\end{array}$ \\
\hline Ground & 271.7 & 394 & 122.3 \\
Contaminated & 481.4 & 452.4 & -29 \\
& & & 93.3 \\
\hline
\end{tabular}

(Ataei and Yoo 2010). After optimization of the water consumption, availability of water in sugar mill is shown in Table 5. The data represent that the ground water consumption is $261.8 \mathrm{~m}^{3} /$ day and average is $384 \mathrm{~m}^{3} /$ day, and the contaminated consumption $491.5 \mathrm{~m}^{3} /$ day and average is $462.3 \mathrm{~m}^{3} /$ day. The subtotal consumption was $93 \mathrm{~m}^{3} /$ day. Unfortunately, there is no reasonable rule for placing regeneration processes in a water network and drawing the diagrams as well. This research provides a method based on analysis of single contaminant consideration for regeneration placement.

\section{Conclusion}

The physicochemical value of the sugar industry effluent is very high which cross the standard limit. If it is not treated, it affects the ecology system. Physico-chemical and biological methods are generally used to treat the sugar industries' effluent. The treated effluent of sugar industries is well balanced in chemicals if it is diluted with other fresh water and can be used for irrigation purpose. Effluents which are released from sugar industry after treatment may be utilized for industrial processing again. Alternative way is recycling rise of waste water and it is economically profitable for sugar industry. Water pinch analysis provides us with a systematic framework for accomplishing process objectives optimally. By identification, 12 sources and 6 sinks demonstrate a surplus of water in this process. The target for fresh water requirement was $1,980.47 \mathrm{~m}^{3} /$ day and requirement was successfully lowered achieving a reduction of approximately $85 \%$. A decrease in net effluent outflow from the process was also observed. The methodology is flexible and can handle large processes.

Open Access This article is distributed under the terms of the Creative Commons Attribution License which permits any use, distribution, and reproduction in any medium, provided the original author(s) and the source are credited.

\section{References}

Adekunle AS, Eniola ITK (2008) Impact of industrial effluents on quality of segment of Asa river within an industrial estate in Ilorin, Nigeria. NY Sci J 1(1):17-21

Ahmad S, Mahmoud TA (1982) Wastewater from a sugar refining industry. Water Res 16:345-355

Amathussalam MN, Abubaker, Jayabai N (2002) Impact of sugar-mill effluent on ground water: a case study. J Ind Poll 18 (2):119-124

American Public Health Association (1995) Standard Methods for Estimation of Water and Wastewater, 19th ed. American Water Works Association, Water environment Federation, Washington, DC

Ataei A, Yoo CK (2010) Simultaneous energy and water optimization in multiple-contaminant systems with flowrate changes consideration. Int J Environ Res 4(1):11-26

Ataei A, Panjeshahi MH, Gharaie M, Tahouni N (2009) New method for designing an optimum distributed cooling system for effluent thermal treatment. Int J Environ Res 3(2):155-166

Avasan M, Rao SR (2001) Effect of sugar mill effluent on organic resources of fish. Poll Res 20(2):167-171 
Baskaran L, Sundaramoorthy P, Chidambaram ALA, Ganesh KS (2009) Growth and physiological activity of greengram (Vigna radiata L.) under effluent stress. Biol Res Int 2(2):107-114

Botha T, Blottnitz HV (2006) A comparison of the environmental benefits of bagasse derived electricity and fuel ethanol on a lifecycle basis. Energy Policy 34:2654-2661

Brown E, Skougstad MW, Fishman MJ (1970) Methods for collection and analysis of water samples for dissolved minerals and gases, Techniques of Water Resources Investigations of the U.S. Geological Survey, 160

Buvaneswaril S, Damodarkumar S, Murugesan S (2013) Bioremediation studies on sugar-mill effluent by selected fungal species. Int J Curr Microbiol Appl Sci 2(1):50-58

Chaudhari PK, Mishra IM, Chand S (2005) Catalytic thermal treatment (catalytic thermolysis) of a biodigester effluent of an alcohol distillery plant. Ind Eng Chem Res 44:5518-5525

Contreras AM, Elena R, Maylier P, Langenhove HV, Dewulf J (2009) Comparative life cycle assessment of four alternatives for using by-products of cane sugar production. J Clean Prod 17:772-779

Devi A (1980) Ecological studies of limon plankton of three fresh water body, Hyderabad. Ph.D. thesis Osmania University, Hyderabad

Devi R, Singh R, Kumar R (2008) COD and BOD reduction from coffee processing wastewater using Avacado peel carbon. Bioreso Tech 99:1853-1860

Doke KM, Khan EM, Rapolu J, Shaikh A (2011) Physico-chemical analysis of sugar industry effluent and its effect on seed germination of Vigna angularis, Vigna cylindrica and Sorghum Cerium. Aunn Environ Sci 5:7-11

Droste RL (1997) Theory and practice of water and wastewater treatment. Wiley, New York

El-Halwagi MM, Gabriel F, Harell D (2003) Rigorous graphical targeting for resource conservation via material recycle/reuse networks. Ind Eng Chem Res 42:4319-4328

Fakayode SO (2005) Impact of industrial effluent on water quality of receiving Alaro river in Ibadan. J Environ Assess Mang 10:1-3

Hampannavar US, Shivayogimath CB (2010) Anaerobic treatment of sugar industry wastewater by up flow anaerobic sludge blanket reactor at ambient temperature. Int J Eng Sci 1(4):55-63

Indian Council of Medical Research (1975) Manual of standards of quality for drinking water supplies

Indian Sugar Manufacturing Assassinations (ISMA) (2014) www. indiansugar.com/Statics.aspx

Jadhav PG, Vaidya NG, Dethe SB (2013) Characterization and comparative study of cane sugar industry wastewater. Int J Chem Phys Sci 2(2):19-25

Kazantzi V, El-Halwagi MM (2005) Targeting material reuse via property integration. Chem Eng Prog 101(8):28-37

Khan M, Kalsoom U, Mahmood T, Riaz M, Khan AR (2003) Characterization and treatment of industrial effluent from sugar industry. J Chem Soc 25(3):256-267

Kolhe AS, Sarode AG, Ingale SR (2009) Study of effluent from sugar cane industry. Sodh Samiksha Mulyankan 2:303-306

Kushwaha JP (2013) A review on sugar industry wastewater: sources, treatment technologies, and reuse, Desal. Water Treat doi:10. $1080 / 19443994.2013 .838526$
Lichts FO (2007) International and sweetener report. Int Sugar J 12:139-145

Macedo I (1998) Greenhouse gas emissions and energy balances in bio-ethanol production and utilization in Brazil. Biomater Bioeng 14(1):77-81

Manal SR (2002) Physico chemical Analysis of effluent from sugar Industry. Dissertation Report Dr. B.A.M.U., Aurangabad

Matkar LS, Gangotri MS (2002) Physico chemical analysis of sugar industrial effluents. J Ind Poll Con 18(2):139-144

Mehrdadi N, Joshi SG, Nasrabadi T, Hoveidi H (2007) Aplication of solar energy for drying of sludge from pharmaceutical industrial waste water and probable reuse. Int J Environ Res 1(1):42-48

Metcalf, Eddy (2003) Wastewater engineering: treatment and reuse, 4th edn. McGraw-Hill, Boston

Mohan KST (1980) Alimnology of the Orman sugar and mill alom lake. Ph. D. thesis Osmania University, Hyderabad

Nakane K, Haidary A (2010) Sensitivity analysis of stream water quality and land cover linkage models using Monte Carlo method. Int J Environ Res 4(1):121-130

Ogedengbe K, Akinbile CO (2004) Impact of industrial pollutants on quality of ground and surface waters at Oluyole industrial estate, Ibadan, Nigeria. Nigeria J Tech Dev 4(2):139-144

Prakash R, Shenoy U (2005) Targeting and design of water networks for fixed flowrate and fixed contaminant load operations. Chem Eng Sci 60:255-268

Prakash R, Henham A, Bhat I (1998) Net energy and gross pollution from bio-ethanol production in India. Fuel 77(14):1629-1633

Rainwater FH, Thatcher LL (1990) Methods for collection and analysis of water samples. US Geologr Survey Papers 1454:1-301

Ramjeawon T (2008) Life cycle assessment of electricity generation from bagasse in Mauritius. J Clean Prod 16:1727-1734

Renouf MR, Wegener MK, Nielsen LK (2008) An environmental life cycle assessment comparing Australian sugarcane with US corn and UK sugar beet as producers of sugars for fermentation. Biomater Bioeng 208:1144-1155

Salequzzaman M, Tariqul Islam SM, Tasnuva A, Kashem MA, Mahedi al Masud M (2008) Environmental impact of sugar industry - a case study on Kushtia sugar mills in Bangladesh. J Innov Dev Strategy 2(3):31-35

Samuel S, Muthukkaruppan SM (2011) Physico-chemical analysis of sugar mill effluent, contaminated soil and its effect on seed germination of paddy. Int J Pharm Biol Arch 2(5):1469-1472

Senthi K, Swamy RDN, Ramkrishan RK (2001) Pollution studies on sugar mill effluent physicochemical characteristics and toxic metals. Poll Res 20(1):19-97

Thorat SP, Wagh SB (1990) Physico chemical analysis of tannery water. J Ind Poll Con 16(1):107-109

Welch EB (1998) Ecological effect of waste water press syndicate of the University of Cambridge, 377

Yoo K, Lee T, Jung H, Hang C (2006) Water reuses network design in process industries: state of the art. Monograph (Eco-Industrial Park Workshop) 